\title{
A combined approach to evaluate activity and structure of soil microbial community in long-term heavy metals contaminated soils
}

\author{
Tianqi Wang ${ }^{1^{*}}$, Zhimin Yuan ${ }^{1^{*}}$, Jun Yao ${ }^{1,2^{+}}$ \\ ${ }^{1}$ School of Energy \& Environmental Engineering, and National International Cooperation Base on Environment and Energy, University of Science and \\ Technology Beijing, 30 Xueyuan Road, Haidian District, Beijing 100083, China \\ ${ }^{2}$ School of Water Resource and Environmental Engineering, Sino-Hungarian Joint Laboratory of Environmental Science and Health, China University of \\ Ceosciences (Beijing), 29 Xueyuan Road, Haidian District, Beijing 100083, China \\ * These authors contributed equally to this work.
}

\begin{abstract}
In the present study, long-term heavy metals ( $\mathrm{HMs}$ ) contaminated soil samples from a well-known $\mathrm{Pb} / \mathrm{Zn}$ smelting area in the southwest of China were collected, and physicochemical and biological characteristics of these samples were evaluated. Soil samples contained different concentrations of $\mathrm{HMs}$, namely $\mathrm{Pb}, \mathrm{Zn}, \mathrm{Cu}$, and $\mathrm{Cd}$. Enzyme activity analyses combined with microcalorimetric analysis were used for soil microbial activity evaluation. Results showed that two soil samples, containing almost the highest concentrations of HMs, also shared the greatest microbial activities. Based on correlation coefficient analysis, high microbial activity in heavily HMs contaminated soil might be due to the high contents of soil organic matter and available phosphorus in these samples. High-throughput sequencing technique was used for microbial community structure analysis. High abundance of genera Sphingomonas and Thiobacillus were also observed in these two heavily contaminated soils, suggesting that bacteria belonging to these two genera might be further isolated from these contaminated soils and applied for future studies of HMs remediation. Results of present study would contribute to the evaluation of microbial communities and isolation of microbial resources to remediate HMs pollution.
\end{abstract}

Keywords: Enzyme activity, Heavy metals, Microbial activity, Microcalorimetric analysis

\section{Introduction}

Soil plays a fundamental role in ecosystem functioning, and thus it is critical to safeguard soil health [1]. However, soil heavy metals (HMs) pollution has become a severe problem in many parts of the world [2]. For instance, up to $20 \%$ of China's arable lands were predicted to be contaminated by HMs [3]. Hezhang County, located in the northwestern part of Guizhou Province (China) and in the upper reaches of the Yangtze River, is well-known for its long history of $\mathrm{Pb} / \mathrm{Zn}$ smelting activities [4]. Moreover, farmland soils in this region also suffered severe HMs pollution due to the careless discharge of wastes during smelting activities. Our previous studies found that farmland soils in this region were heavily contaminated by multiple $\mathrm{HMs}$, including $\mathrm{Pb}, \mathrm{Zn}$ and Cd [5]. HMs pollution in this region would cause serious harm to local residents, as well as to residents in the lower reaches of Yangtze River. Thus, it is important to develop and implement strategies to reduce the environmental hazard of soil HMs pollutions.

Recently, bioremediation has achieved much attention, because it is low-cost, environmental-friendly, and efficient [6]. Bacteria and fungi, isolated from HMs contaminated soils or sediments, have been widely used for remediation of HMs [7, 8]. Under long-term HMs stress, microbial communities could develop different mechanisms to tolerate HMs [9], and long-term HMs contaminated soils could be sinks of HMs-tolerant microorganisms, which could be used for HMs bioremediation. Lots of studies had been conducted to analyze the effects of HMs on soil microbial community structure and functions, but contrasting results were reported in the literature. Some reported that long-term HMs contamination reduced soil microbial activity and diversity, reflecting the toxic effects of HMs on soil microbial community [10, 11]; while others reported that activity of a well-adapted microbial community in heavily contaminated soil was not obviously affected
This is an Open Access article distributed under the terms of the Creative Commons Attribution Non-Commercial License (http://creativecommons.org/licenses/by-nc/3.0/) which permits unrestricted non-commercial use, distribution, and reproduction in any medium, provided the original work is properly cited.
Received May 17, 2017 Accepted August 23, 2017

${ }^{\dagger}$ Corresponding author

Email: yaojun@ustb.edu.cn

Tel: +86-10-82321958

Copyright (C) 2018 Korean Society of Environmental Engineers 
by HMs contaminations [12, 13]. Moreover, under natural conditions, metal effects on soil microorganisms are influenced by soil properties, such as organic matter $(\mathrm{OM})$ content, $\mathrm{pH}$, and the availability of $\mathrm{N}, \mathrm{P}$, and $\mathrm{K}$ [14]. Thus, the microbial characterization of HMs contaminated soils could reveal the adaptation of soil microbial community to different environmental factors, and thus benefit the isolation of HMs tolerant microorganisms.

Soil microbial activity is often evaluated for HMs contaminated soils [15]. In the present study, activity analyses of two different enzymes, namely fluorescein diacetate (FDA) hydrolysis and urease, combined with microcalorimetric analysis were conducted to predict soil microbial activity. Activity of FDA hydrolysis has been widely used as an indicator of overall soil microbial activity [16], whereas urease is closely linked to nitrogen mineralization potential and is required in converting urea into a usable form for plants [17]. Microcalorimetry can detect the metabolic heat flux produced during microbial growth, thus providing quantitative information on growth process [18], and lots of studies had already used microcalorimetry to quantitatively evaluate the effects of different pollutants on soil microbial activity [19, 20]. Additionally, MiSeq high-throughput sequencing technique was used to analyze soil bacterial community structure, because it provides a direct way to detect the microbial taxa [21], especially for those with low abundance. This approach has been widely used in analysis of soil microbial structure in different contaminated sites [12, 22].

In the present study, soil samples were collected from long-term contaminated sites, and the physicochemical and microbiological characteristics of these samples were evaluated. The objectives of present study were: 1) to investigate the impacts of HMs contamination combined with other soil properties on soil microbial community; and 2) to reveal the adaptation of soil microbial community to long-term HMs stress. Results of present study could contribute to the isolation of microbial resources, as well as the bioremediation strategies of HMs contaminated sites.

\section{Materials and Methods}

\subsection{Soil Sampling}

Soil samples were collected near an abandoned ore dressing plant in Hezhang County $\left(104^{\circ} 33^{\prime}\right.$ E, $26^{\circ} 58^{\prime} \mathrm{N}$ ). This area is covered by red soil, which is widely distributed in Guizhou Province. Five different top soil $(0-20 \mathrm{~cm})$ samples (S1 to S5), contaminated by increasing concentrations of $\mathrm{Pb}$, were collected based on preliminary in situ determination results using a Niton XL3t-800 X-ray fluorescence apparatus (XRF, Thermo Fisher Scientific, USA). All samples were ground and sieved at $<2 \mathrm{~mm}$ to remove plant residuals, soil macro fauna, and stones. Two aliquots were taken for each sample: one aliquot was air-dried, ground, and sieved at $<0.125 \mathrm{~mm}$ for determination of soil physicochemical characteristics and HMs concentrations. The other aliquot was stored at $4^{\circ} \mathrm{C}$ for subsequent microbial activity and community analyses.

\subsection{Determination of Soil Physicochemical Properties}

Soil $\mathrm{pH}$ value was determined using a $\mathrm{pH}$-meter (OHAUS Starter 2C) by immersing the electrode into the supernatant of the soil suspension (distilled water-to-soil ratio was 5:1, w/w). OM content was determined by the potassium dichromate volumetric method quoted by Xun et al [23]. Total nitrogen content was determined by the Kjeldahl method [24, 25]. Available phosphorus content was determined using the Olsen method described by Jones et al [26]. Available potassium content was determined by flame photometry after ammonium acetate extraction [27].

Total concentrations of HMs were determined after digestion in aqua regia. Available HMs were extracted using $0.1 \mathrm{M} \mathrm{HCl}$ at $180 \mathrm{r} / \mathrm{min}$ for $1.5 \mathrm{~h}$ [28]. HMs concentrations in extraction solutions were then determined using an inductively coupled plasmaoptical emission spectrometer (ICP-OES, iCAP 7200, Thermo Fisher Corporation, USA).

\subsection{Determination of Soil Enzyme Activities}

FDA hydrolysis activity was determined using the method quoted by Yuan et al [29]. The determination was conducted after incubating soil samples with FDA solution for $20 \mathrm{~min}$ at $28^{\circ} \mathrm{C}$. The concentration of fluorescein released from FDA hydrolysis was measured spectrophotometrically at $490 \mathrm{~nm}$. FDA hydrolysis activity was expressed as $\mu \mathrm{g}$ fluorescein/g soil.

Urease activity was determined using a modified method according to previous literature [20]. The determination was conducted after the incubation of soil samples with a urea solution for 2 $\mathrm{h}$ at $37^{\circ} \mathrm{C}$. The concentration of $\mathrm{NH}_{4}{ }^{+}$ions released from urea hydrolysis was determined spectrophotometrically at $578 \mathrm{~nm}$. Urease activity was expressed as $\mu \mathrm{g} \mathrm{NH}_{3}-\mathrm{N} / \mathrm{g}$ soil.

\subsection{Microcalorimetric Analysis}

A TAM-III multi-channel thermal activity microcalorimeter (TA Instruments, Delaware, USA) was used for the microcalorimetric measurements of soil samples. For each sample, $1.0 \mathrm{~g}$ of soil was weighed into a $4.5 \mathrm{~mL}$ steel ampoule, and then $0.2 \mathrm{~mL}$ of nutrient solution (containing $5.0 \mathrm{mg}$ of glucose and $5.0 \mathrm{mg}$ of ammonium sulfate) was added [30]. Ampoules were put inside the microcalorimeter for heat flow recording at $28^{\circ} \mathrm{C}$ until the signal returned to baseline.

Two microcalorimetric parameters, namely $t_{\max }$ (min, the time required to reach the maximum heat output) and $P_{\max }(\mu \mathrm{W}$, the maximum heat output), could be obtained directly from the powertime curve for each sample. The microbial growth rate constant $k\left(\min ^{-1}\right)$ was obtained from the equation:

$$
\ln P_{t}=\ln P_{0}+k t
$$

where $P_{\mathrm{t}}$ is the power output at time t, and $P_{0}$ is the power at the beginning of the exponential growth phase.

\subsection{Bacterial Community Structure Analysis}

For each sample, $1.0 \mathrm{~g}$ of soil was used for soil DNA extraction using Soil DNA Kit (Omega Bio-tek, GA, USA) according to the manufacturer's protocols. PCR amplification of V3-V4 regions of bacterial 16S rRNA was performed in GeneAmp PCR-System ${ }^{\circledR}$ 9700 (Applied Biosystems, CA, USA), using universal primers as 338F (5'-ACT CCT ACG GGA GGC AGC AG-3') and 806R (5'-GGA CTA CHV GGG TWT CTA AT-3'). PCR amplification reaction was 
carried out in a $20 \mu \mathrm{L}$ mixture containing $4 \mu \mathrm{L}$ of $5 \times$ FastPfu Buffer, $2 \mu \mathrm{L}$ of dNTPs, $0.8 \mu \mathrm{L}$ of each primer solution, $0.4 \mu \mathrm{L}$ of FastPfu Polymerase, and 10 ng of $4 \mu \mathrm{L}$ DNA template. The procedure of PCR amplification reaction was as follows: $95^{\circ} \mathrm{C}$ for $3 \mathrm{~min}$; and 27 cycles of $95^{\circ} \mathrm{C}$ for $30 \mathrm{~s}, 55^{\circ} \mathrm{C}$ for $30 \mathrm{~s}$, and $72^{\circ} \mathrm{C}$ for $45 \mathrm{~s} ; 72^{\circ} \mathrm{C}$ for $10 \mathrm{~min}$. PCR amplification products were detected using $2 \%$ agarose gel electrophoresis and extracted using AxyPrep DNA Gel Extraction Kit (Axygen Biosciences, CA, USA). Purified amplification products were sequenced on an Illumina MiSeq platform at Shanghai Majorbio Biotech Co., Ltd. Sequencing data were analyzed according to the method described by Zhang et al [31]. The taxonomic classification of each sequence was analyzed by RDP Classifier against the Silva database using confidence threshold of 0.70 .

\subsection{Statistical Analysis}

All parameters were detected with three replicates and results were given in mean value. Correlation coefficient analysis were performed by SPSS PSSW statistics 18.0 (SPSS Inc., New York, USA), and graphs were prepared using Origin 8.5 (OriginLab, MA, USA).

\section{Results and Discussion}

\subsection{Soil Physicochemical Characteristics}

The chemical parameters of five soil samples were shown in Table 1. All soil samples were slightly acidic. S2 had the highest contents of total nitrogen $(\mathrm{N})$, available phosphorus (P), and OM, namely $1.68 \mathrm{~g} / \mathrm{kg}, 36.19 \mathrm{mg} / \mathrm{kg}$, and $102.66 \mathrm{~g} / \mathrm{kg}$, respectively. S3 had the highest available potassium (K) content as $241.05 \mathrm{mg} / \mathrm{kg}$. S1 had the lowest contents of total $\mathrm{N}(0.52 \mathrm{~g} / \mathrm{kg})$, available P $(6.04 \mathrm{mg} / \mathrm{kg})$, available K (78.04 mg/kg), and OM (20.50 g/kg), showing its lowest nutrient contents.

\subsection{Soil HMs Concentrations}

Table 1 summarized the concentrations of total and available HMs in these samples. Except for S1 with the concentration of total
$\mathrm{Pb}$ being $<80 \mathrm{mg} / \mathrm{kg}$, the Grade II standard value established by Ministry of Environmental Protection of the People's Republic of China, the other samples had increasing concentrations of $\mathrm{Pb}$ higher than the standard value. Especially, the highest concentration of total $\mathrm{Pb}(759.3 \mathrm{mg} / \mathrm{kg})$, observed at S5, was almost 9.49-fold of the standard value. Except for $\mathrm{Pb}$, high concentrations of other $\mathrm{HMs}$, namely $\mathrm{Zn}, \mathrm{Cu}$, and $\mathrm{Cd}$, were also observed in these samples. Total $\mathrm{Zn}$ concentrations of these samples were higher than the standard value $(200 \mathrm{mg} / \mathrm{kg})$. The highest concentration of total $\mathrm{Zn}$ at S4 $(2,119.3 \mathrm{mg} / \mathrm{kg})$ was 10.60 -fold of its standard value. Total $\mathrm{Cu}$ concentrations of these samples were obviously greater than the standard value for total $\mathrm{Cu}(50 \mathrm{mg} / \mathrm{kg}$ ). For total $\mathrm{Cd}$, the highest concentration was $27.3 \mathrm{mg} / \mathrm{kg}$ at S4, followed by the value at S2 as $11.9 \mathrm{mg} / \mathrm{kg}$, which were 90.97 - and 39.80 -fold of its standard value. These results reflected the enrichment of these HMs caused by human activities. However, total HMs concentrations in long-term contaminated soils could not be precise indices for evaluating the effects of HMs on soil microorganisms [32], because HMs bioavailability can change following their physicochemical interactions with the soil matrix [13]. Thus, concentrations of $0.1 \mathrm{M} \mathrm{HCl}$ extracted $\mathrm{HMs}$ were also determined to predict their bioavailability. S5 had the highest concentration of $0.1 \mathrm{M} \mathrm{HCl}$ extracted $\mathrm{Pb}(\mathrm{HCl}-\mathrm{Pb})$ as $681.0 \mathrm{mg} / \mathrm{kg}$. Slight variations were observed in $\mathrm{HCl}-\mathrm{Zn}$ concentrations of samples S2-S4, which were still higher than that of S1. Samples S4 and S2 shared the highest concentrations of $\mathrm{HCl}-\mathrm{Cd}$, as $18.9 \mathrm{mg} / \mathrm{kg}$ and $7.6 \mathrm{mg} / \mathrm{kg}$, respectively.

\subsection{Soil Microbial Activities}

Table 2 summarized the results of two soil enzyme activity analyses. S4 had the greatest value of FDA hydrolysis activity as 67.17 $\mu \mathrm{g}$ fluorescein/g soil, followed by that of S2, which was 64.82 $\mu \mathrm{g}$ fluorescein/g soil. All the values of FDA hydrolysis activity followed a trend as S4 $>$ S2 $>$ S3 $>$ S5 $>$ S1. Urea activity also showed large inter-sample variations. Urease activities at S2 and S4 were the greatest among these samples, which were $125.02 \mu \mathrm{g}$

Table 1. Main Physicochemical Properties of Soil Samples $($ mean $\pm S D, n=3)$

\begin{tabular}{lccccr}
\hline \multicolumn{1}{c}{ Soil samples } & S1 & S2 & S3 & S4 & S5 \\
\hline $\mathrm{pH}$ & $6.14 \pm 0.09$ & $6.35 \pm 0.08$ & $6.11 \pm 0.04$ & $5.91 \pm 0.03$ & $6.32 \pm 0.05$ \\
Total N (g/kg) & $0.52 \pm 0.06$ & $1.68 \pm 0.07$ & $0.66 \pm 0.05$ & $1.25 \pm 0.08$ & $0.59 \pm 0.06$ \\
Available P (mg/kg) & $6.04 \pm 0.35$ & $36.19 \pm 1.91$ & $31.89 \pm 2.27$ & $31.89 \pm 0.71$ & $9.43 \pm 0.51$ \\
Available K (mg/kg) & $78.04 \pm 0.52$ & $103.62 \pm 1.66$ & $241.05 \pm 1.3$ & $92.04 \pm 1.22$ & $122.34 \pm 1.51$ \\
$\mathrm{OM} \mathrm{(g/kg)}$ & $20.50 \pm 4.62$ & $102.66 \pm 3.71$ & $36.32 \pm 1.19$ & $98.04 \pm 0.86$ & $35.08 \pm 3.92$ \\
$\mathrm{~Pb} \mathrm{(mg/kg)}$ & $67.4 \pm 1.6$ & $361.7 \pm 7.7$ & $435.4 \pm 2.8$ & $738.1 \pm 7.7$ & $759.3 \pm 11.4$ \\
$\mathrm{Zn} \mathrm{(mg/kg)}$ & $307.3 \pm 12.2$ & $1,161.3 \pm 22.1$ & $749.0 \pm 17.6$ & $2,119.3 \pm 15.1$ & $1,112.7 \pm 13.3$ \\
$\mathrm{Cu}(\mathrm{mg} / \mathrm{kg})$ & $272.3 \pm 7.1$ & $239.4 \pm 4.3$ & $275.9 \pm 5.6$ & $291.4 \pm 2.3$ & $373.7 \pm 0.4$ \\
$\mathrm{Cd}(\mathrm{mg} / \mathrm{kg})$ & $3.7 \pm 0.2$ & $11.9 \pm 0.9$ & $5.9 \pm 0.3$ & $27.3 \pm 1.3$ & $7.2 \pm 0.2$ \\
$\mathrm{HCl}-\mathrm{Pb} \mathrm{(mg/kg)}$ & $33.0 \pm 1.9$ & $106.8 \pm 2.8$ & $258.8 \pm 29.3$ & $245.3 \pm 9.4$ & $681.0 \pm 33.9$ \\
$\mathrm{HCl}-\mathrm{Zn} \mathrm{(mg/kg)}$ & $62.2 \pm 2.0$ & $191.0 \pm 2.1$ & $166.7 \pm 7.3$ & $222.4 \pm 1.9$ & $206.9 \pm 1.5$ \\
$\mathrm{HCl}-\mathrm{Cu}(\mathrm{mg} / \mathrm{kg})$ & $17.2 \pm 0.2$ & $14.3 \pm 0.2$ & $41.0 \pm 1.6$ & $31.0 \pm 1.1$ & $69.3 \pm 2.7$ \\
$\mathrm{HCl}-\mathrm{Cd}(\mathrm{mg} / \mathrm{kg})$ & $2.1 \pm 0.2$ & $7.6 \pm 0.2$ & $3.5 \pm 0.1$ & $18.9 \pm 0.8$ & $4.5 \pm 0.1$ \\
\hline
\end{tabular}


$\mathrm{NH}_{3}-\mathrm{N} / \mathrm{g}$ soil and $23.74 \mu \mathrm{g} \mathrm{NH}_{3}-\mathrm{N} / \mathrm{g}$ soil, respectively. The values of urease activity followed a trend as $\mathrm{S} 2>\mathrm{S} 4>\mathrm{S} 3>\mathrm{S} 5>\mathrm{S} 1$.

As shown in Fig. 1, differences in the shape of the power-time curves of soil samples were observed, showing the large variations in their microbial metabolic activities. The microcalorimetric parameters $\left(P_{\max }, t_{\max }\right.$, and $\left.k\right)$, calculated from the power-time curves, were shown in Table 2. S4 had the greatest value of $P_{\max }$ as 779.59 $\mu \mathrm{W}$. S2 also shared higher value of $P_{\max }$ when compared with others, which was $477.91 \mu \mathrm{W}$. The trend in $P_{\max }$ values is the same as that of FDA hydrolysis activity values. The $t_{\max }$ values could represent differences in metabolic activities of soil microorganisms, and a high $t_{\max }$ value might represent a consequence of metabolism delay [29]. S2 shared the lowest value of $t_{\max }$ as $1,037.00 \mathrm{~min}$, suggesting that microorganisms in this sample might share the most sensitivity and ability to consume the added glucose and thus produce heat. Soil microbial growth rate constant $k$ values reflect differences in the amplification rate of soil microorganisms during the exponential growth period [30]. S2 and S4 shared the greatest values of $k\left(4.26 \times 10^{-3} \mathrm{~min}^{-1}\right.$ and $3.73 \times 10^{-3} \mathrm{~min}^{-1}$, respectively), while S1 shared the lowest value of $k$ as $2.06 \times$ $10^{-3} \mathrm{~min}^{-1}$. The trend in $k$ values was $\mathrm{S} 2>\mathrm{S} 4>\mathrm{S} 3>\mathrm{S} 5>$ $\mathrm{S} 1$, which was the same as that of urease activity values.

Earlier studies suggested that higher $P_{\max }$ value, lower $t_{\max }$ value, and higher $k$ value were good indicators of high microbial activity [33]; meanwhile, FDA hydrolysis and urease activities are also related with soil microbial activity. Both enzyme activity and microcalorimetric analyses showed that S2 and S4 shared relatively higher microbial activity than others, although these two samples also contained relatively higher concentrations of total and available HMs. However, S1 shared the lowest microbial activity, al though HMs concentrations in this sample were the lowest. These results were contrary to some studies, which reported negative relationships between HMs concentrations and soil microbial activities [10, 11].

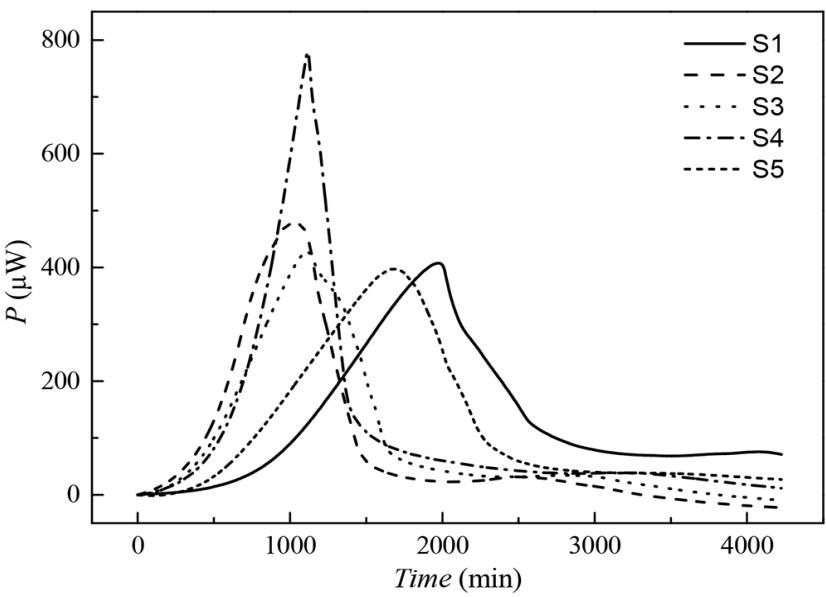

Fig. 1. Power-time curves recorded microcalorimetrically from samples amended with glucose and ammonium sulfate.

Correlation coefficient analysis was performed to find the possible relationships between physicochemical parameters and microbial activity related parameters, and results were shown in Table 3. Significantly positive correlations were observed between OM and soil microbial activity related parameters, namely OM-FDA hydrolysis activity $(0.94, p<0.01)$ and OM- $k(0.93, p<0.01)$. Meanwhile, available $\mathrm{P}$ also showed significantly positive correlation with FDA hydrolysis activity $(0.92, p<0.01)$ and $k(0.93, p<0.01)$. Total $\mathrm{N}$ also positively correlated with FDA hydrolysis activity $(0.89$, $p<0.01)$ and $k(0.94, p<0.01)$. These results reflected the stimulation effects of $\mathrm{OM}$, available $\mathrm{P}$, and total $\mathrm{N}$ on soil microbial activity, and two possible reasons could be taken into consideration when analyzing their effects on soil microbial activity in HMs contaminated soil. Firstly, these substances could be used as

Table 2. The Results of Enzyme Activity and Microcalorimetric Analyses (mean $\pm S D, n=3$ )

\begin{tabular}{|c|c|c|c|c|c|}
\hline \multirow{2}{*}{$\begin{array}{c}\text { Soil } \\
\text { samples }\end{array}$} & \multicolumn{2}{|c|}{ Enzyme activity } & \multicolumn{3}{|c|}{ Microcalorimetric parameters } \\
\hline & $\begin{array}{l}\text { FDA hydrolysis activity } \\
(\mu \mathrm{g} / \mathrm{g} \text { soil })\end{array}$ & $\begin{array}{c}\text { Urease activity } \\
\left(\mu \mathrm{g} \mathrm{NH}_{3}-\mathrm{N} / \mathrm{g} \text { soil }\right)\end{array}$ & $\begin{array}{c}k \\
\left(\min ^{-1} \times 10^{-3}\right)\end{array}$ & $\begin{array}{c}t_{\max } \\
(\min )\end{array}$ & $\begin{array}{c}P_{\text {max }} \\
(\mu W)\end{array}$ \\
\hline $\mathrm{S} 1$ & $30.95 \pm 1.61$ & $9.04 \pm 0.58$ & $2.06 \pm 0.07$ & $1,970.50 \pm 15.50$ & $407.36 \pm 9.18$ \\
\hline S2 & $64.82 \pm 7.00$ & $125.02 \pm 4.08$ & $4.26 \pm 0.13$ & $1,037.00 \pm 22.00$ & $477.97 \pm 20.03$ \\
\hline S3 & $48.49 \pm 3.59$ & $19.22 \pm 5.02$ & $3.04 \pm 0.06$ & $1,115.00 \pm 5.77$ & $427.06 \pm 7.48$ \\
\hline S4 & $67.17 \pm 2.37$ & $23.74 \pm 2.67$ & $3.73 \pm 0.08$ & $1,117.50 \pm 20.02$ & $779.59 \pm 12.65$ \\
\hline S5 & $32.33 \pm 4.90$ & $11.17 \pm 2.43$ & $2.12 \pm 0.06$ & $1,681.50 \pm 13.31$ & $397.19 \pm 11.52$ \\
\hline
\end{tabular}

Table 3. Correlation Matrix between Physicochemical and Biological Parameters of Soil Samples

\begin{tabular}{|c|c|c|c|c|c|c|c|c|c|c|c|c|c|}
\hline & pH & Total N & Available P & Available K & OM & $\mathbf{P b}$ & $\mathrm{Zn}$ & $\mathrm{Cu}$ & Cd & HCl-Pb & HCl-Zn & HCl-Cu & HCl-Cd \\
\hline FDA & -0.31 & $0.89^{*}$ & $0.92^{*}$ & -0.02 & $0.94^{*}$ & 0.28 & 0.73 & -0.53 & 0.78 & -0.32 & 0.60 & -0.43 & 0.77 \\
\hline Urease & 0.49 & 0.87 & 0.61 & -0.17 & 0.71 & -0.15 & 0.15 & -0.60 & 0.14 & -0.36 & 0.26 & -0.52 & 0.12 \\
\hline$k$ & -0.10 & $0.94^{*}$ & $0.93^{*}$ & 0.00 & $0.93^{*}$ & 0.16 & 0.59 & -0.62 & 0.63 & -0.37 & 0.54 & -0.49 & 0.61 \\
\hline$t_{\max }$ & 0.17 & -0.73 & $-0.99 * *$ & -0.40 & -0.76 & -0.36 & -0.59 & 0.42 & -0.55 & 0.12 & -0.68 & 0.17 & -0.54 \\
\hline$P_{\max }$ & -0.74 & 0.52 & 0.50 & -0.30 & 0.71 & 0.47 & $0.89^{*}$ & -0.14 & $0.98^{* *}$ & -0.14 & 0.50 & -0.21 & $0.98^{* *}$ \\
\hline
\end{tabular}

\footnotetext{
${ }^{*}$ Correlation coefficients statistically significant at $p<0.05$
}

${ }^{* *}$ Correlation coefficients statistically significant at $p<0.01$ 

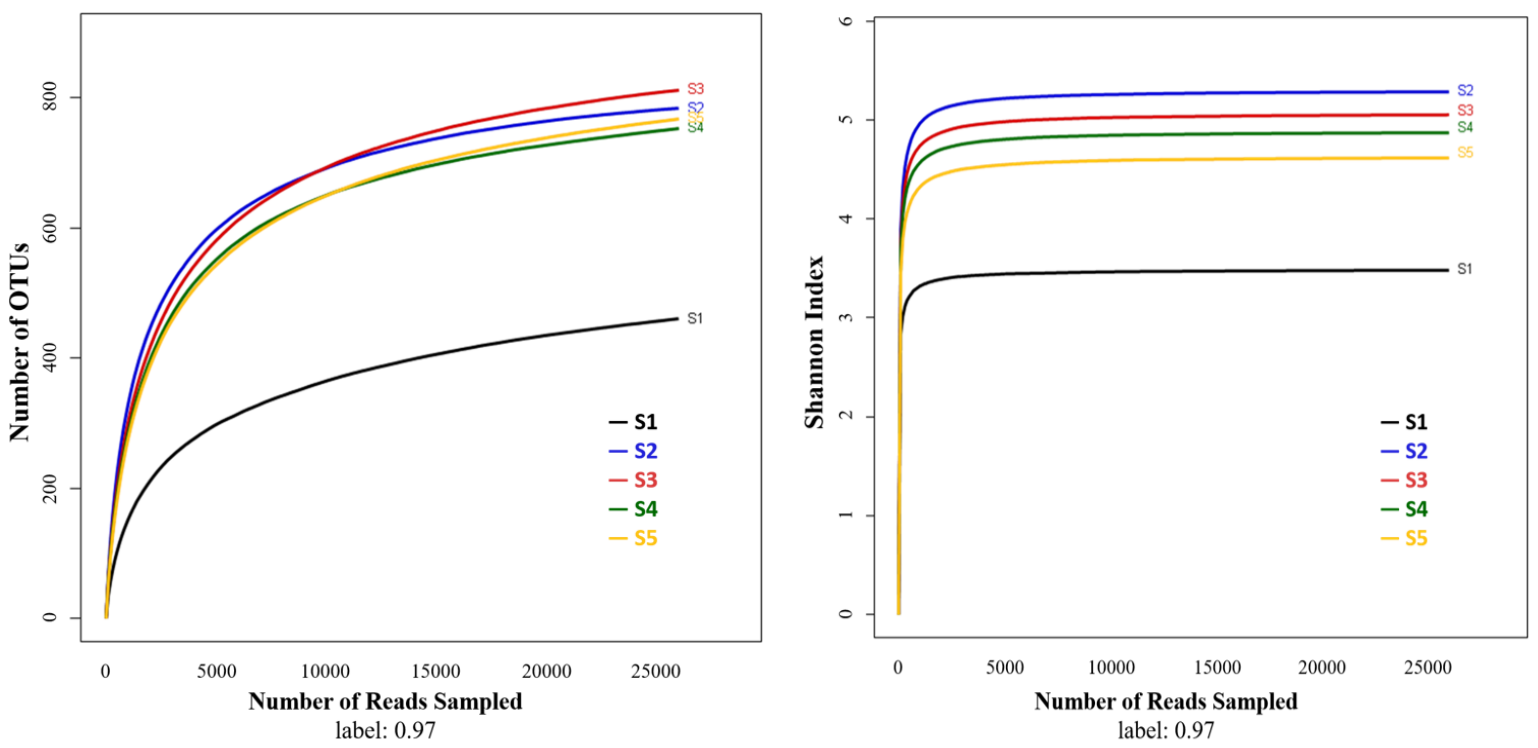

Fig. 2. Rarefaction curves and Shannon curves based on the $16 \mathrm{~S}$ rRNA gene sequencing.

nutrients and carbon sources, which will stimulate the growth of soil microorganism. Secondly, available P and OM could reduce the availability and toxicity of HMs, thus indirectly stimulating soil microbial activity. For instance, phosphate could react with soil mobile HMs, forming more insoluble precipitates such as pyromorphite and reducing the bioavailability of HMs [34]; OM has high surface area and adsorption capacity for cations [35], decreasing their availability [36].

\subsection{Soil Bacterial Community Structure Analysis}

In long-term contaminated soils, the replacement of sensitive microorganisms by resistant ones could be another reason for the high microbial activity in heavily HMs contaminated soils [37]. Thus, bacterial community structures of these samples were analyzed using MiSeq sequencing technique. Totally, 24,746 to 35,137 valid 16S rRNA sequences were obtained per sample, with an average value as 30,303 . Subsampling procedure was conducted for each library based on the minimum sequence value $(24,746)$, and subsequent analyses were carried out based on the subsampled data. Rarefaction and Shannon-Wiener curves were presented in Fig. 2, and all the curves tended to approach the plateau, reflecting that the data volume of valid sequences were reasonable, and could reflect the vast majority of biological information for each library [21].

Taxonomic classification of each sequence revealed significant differences in community structure between these samples (as shown in Fig. 3). At the phylum level, the dominant phyla in S1 were Firmicutes (58.05\%, 14,366 sequences), Proteobacteria (17.52\%, 4,335 sequences), and Chloroflexi (10.70\%, 2,649 sequences). The abundances of phylum Proteobacteria increased in other samples, with relative abundance values from $49.03 \%$ to $64.17 \%$; meanwhile, phylum Acidobacteria only shared a relative abundance value as $4.40 \%$ in S1, and its relative abundance increased to $19.71 \%$ in S2. Phylum Gemmatimonadetes also shared
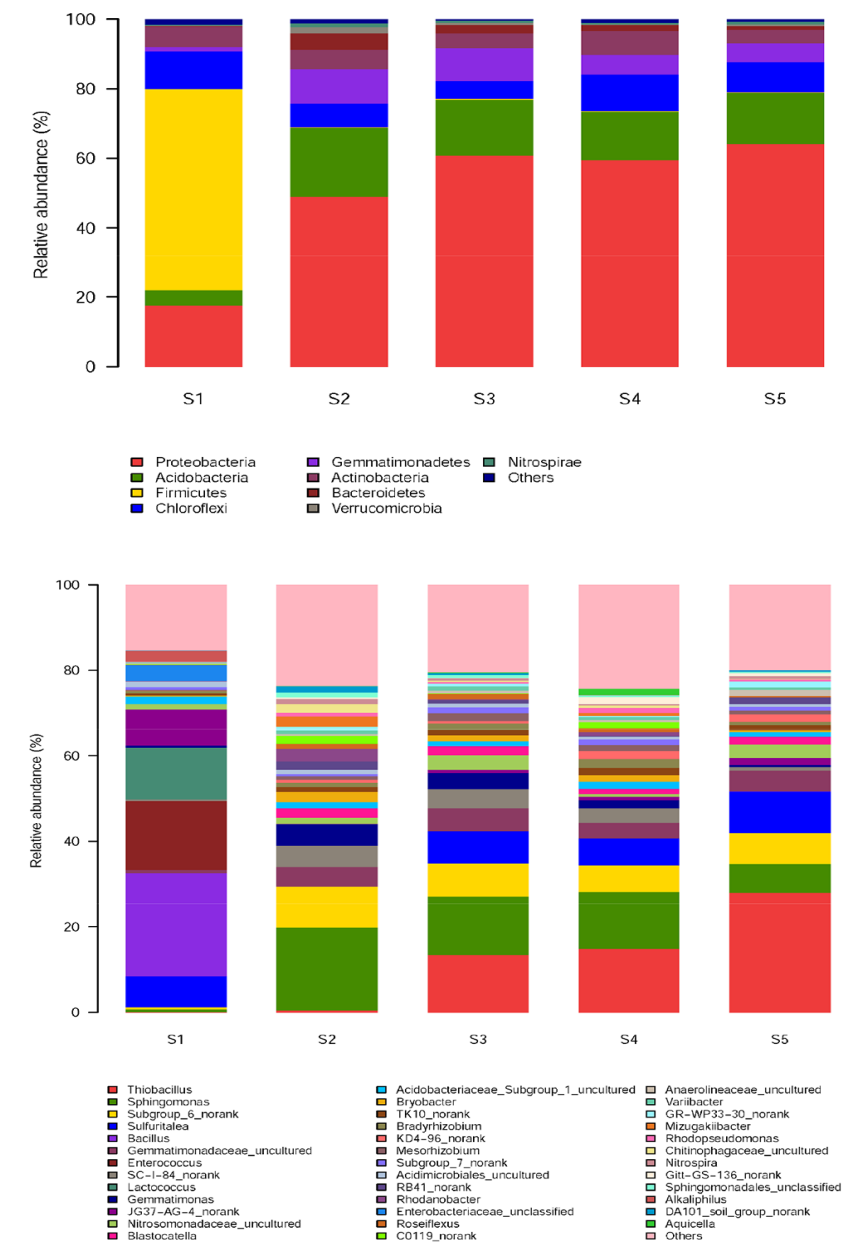
Acidobacter
Firmicutes
Chloroflexi s1
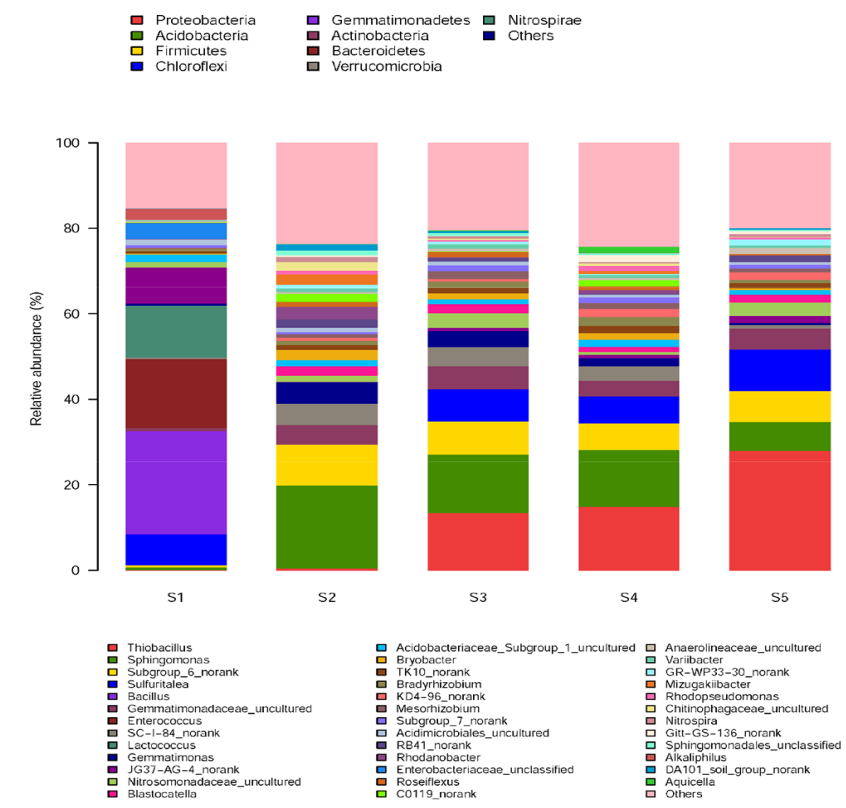

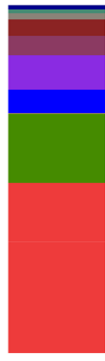

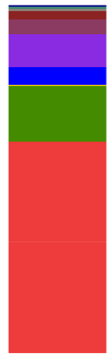

$\mathrm{s} 3$

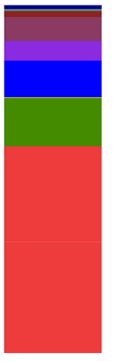

S4

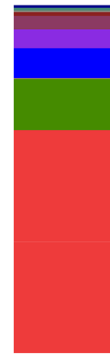

S5
Fig. 3. Relative abundance of different bacterial community structures at phylum (above) and genus (below) levels. 


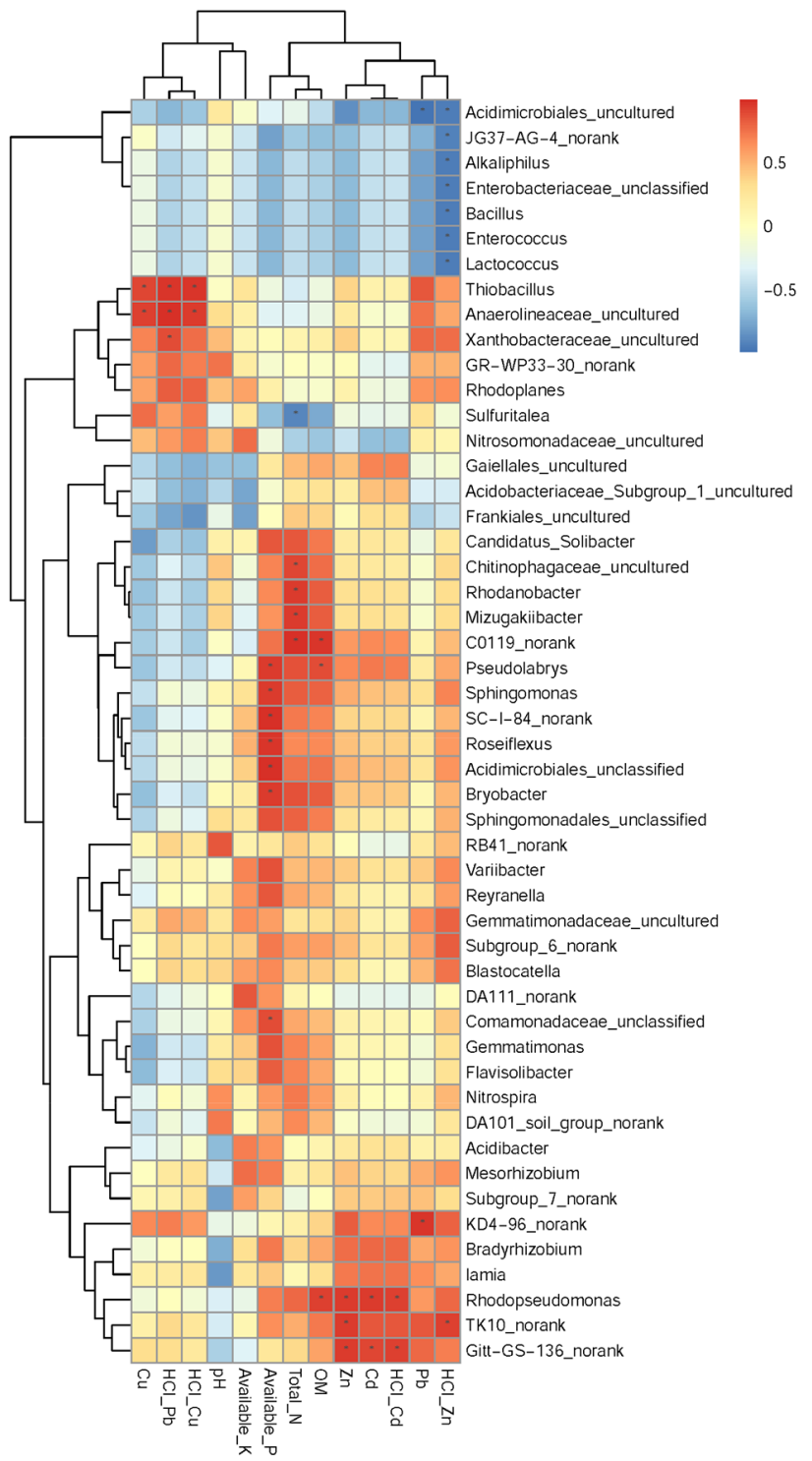

Fig. 4. Heatmap of correlations between environmental factors and genus abundance $(*$ means $p<0.05)$.

a low relative abundance in S1 (1.31\%), and its abundance also increased in other samples. At the genus level, the dominant genera in S1 were Bacillus (24.11\%, 5,967 sequences), Enterococcus (16.11\%, 3,987 sequences), and Lactococcus (12.12\%, 2,998 sequences). Although previous studies reported that some Bacillus spp. had high HMs tolerance ability and had already been used for HMs remediation [38], the abundance of genus Bacillus was very low in other samples. Genus Sphingomonas shared low abundance in S1, but its abundance increased in other HMs contaminated samples. Especially, S2 shared the greatest relative abundance value of genus Sphingomonas as $19.44 \%$. Previous studies demonstrated the abilities of Sphingomonas spp. to degrade toxic organic substances [39], and used a Cd tolerant Sphingomonas sp. to treat Cd containing waters [40]. An earlier study also observed high abundance of genus Sphingomonas in mining areas [41]. Considering the remediation ability and abundance in the contaminated samples, Sphingomonas spp. might be isolated from these contaminated soils, and used for future HMs remediation studies. Genus Thiobacillus shared low abundance in S1 and S2, but its abundance increased in S3-S5, with relative abundance values as $13.45 \%-27.94 \%$. Previous studies had pointed that Thiobacillus spp. could oxidize inorganic sulfur and produce sulphuric acid [42, 43], which would facilitate the mobility of HMs. Therefore, Thiobacillus spp. could also be isolated from these samples and be further studied for potential remediation of contaminated soils through bioleaching procedure.

Correlation analysis was also conducted between different genus abundances and environmental factors (combined with physicochemical parameters and HMs concentrations), and results were shown in Fig. 4. The abundances of general Bacillus, Enterococcus, and Lactococcus, sharing high abundance in S1 all showed significantly $(p<0.05)$ negative correlations with HCl-Zn. Genus Sphingomona shared higher abundance in soils containing higher concentrations of HMs, and its abundance showed significantly $(p<0.05)$ positive correlation with available $\mathrm{P}$ content as 0.95 . However, its abundance showed no obvious correlation with HMs related parameters. The high abundance of genus Sphingomona after microbial community adaptation under HMs stress, combined with high available P content in S2 might explain the higher microbial activity in S2. The abundance of genus Thiobacillus showed significantly $(p<0.05)$ positive correlation with $\mathrm{HCl}-\mathrm{Pb}, \mathrm{HCl}-\mathrm{Cu}$, and $\mathrm{Cu}$, and it also showed positive correlations with $\mathrm{HMs}$ related parameters. The inorganic sulfur, released during discharging of HMs industry wastes, might stimulate the growth of Thiobacillus spp.

\section{Conclusions}

Combined methods were applied to evaluate physicochemical and biological characteristics of long-term HMs contaminated soil. Both enzyme activity and microcalorimetric analyses showed that two of five samples, namely S2 and S4, had the greatest microbial activities, although these two samples contained almost the greatest concentrations of HMs. Correlation coefficient and bacterial community structure analyses demonstrated that high microbial activity in heavily HMs contaminated soil might be due to the stimulation effects of soil OM and available P contents on the well-adapted microbial community. Bacteria belonging to genera Sphingomonas and Thiobacillus might be further isolated for HMs remediation studies. Our findings could contribute to the evaluation of microbial communities for further isolation of HMs tolerant microorganisms and remediation of HMs pollution.

\section{Acknowledgments}

This work is supported in part by grants from Public welfare project of Chinese Ministry of Environmental Protection (201409042, 201509049), Key project from National Natural Science Foundation 
of China (41430106), National Natural Science Foundation of China (41273092, U1402234). The authors express their sincere thanks to Prof. Geoffrey Sunahara for his scientific advice and stimulating discussion.

\section{References}

1. Coppolecchia D, Puglisi E, Vasileiadis S, et al. Relative sensitivity of different soil biological properties to zinc. Soil Biol. Biochem. 2011;43:1798-1807.

2. Li ZY, Ma ZW, van der Kuijp TJ, Yuan ZW, Huang L. A review of soil heavy metal pollution from mines in China: Pollution and health risk assessment. Sci. Total Environ. 2014;468-469:843-853.

3. Li J, Ma YB, Hu HW, Wang JT, Liu YR, He JZ. Field-based evidence for consistent responses of bacterial communities to copper contamination in two contrasting agricultural soils. Front. Microbiol. 2015;6:31.

4. Bi XY, Feng XB, Yang YG, et al. Environmental contamination of heavy metals from zinc smelting areas in Hezhang County, western Guizhou, China. Environ. Int. 2006;32:883-890.

5. Yuan Z, Yao J, Wang F, et al. Potentially toxic trace element contamination, sources, and pollution assessment in farmlands, Bijie City, southwestern China. Environ. Monit. Assess. 2017;189:25.

6. Zhao Y, Yao J, Yuan ZM, Wang TQ, Zhang YY, Wang F. Bioremediation of Cd by strain GZ-22 isolated from mine soil based on biosorption and microbially induced carbonate precipitation. Environ. Sci. Pollut. Res. 2017;24:372-380.

7. Velmurugan P, Shim J, You Y, et al. Removal of zinc by live, dead, and dried biomass of Fusarium spp. isolated from the abandoned-metal mine in South Korea and its perspective of producing nanocrystals. J. Hazard. Mater. 2010;182:317-324.

8. del Carmen Vargas-Garcia M, Jose Lopez M, Suarez-Estrella $\mathrm{F}$, Moreno J. Compost as a source of microbial isolates for the bioremediation of heavy metals: In vitro selection. Sci. Total. Environ. 2012;431:62-67.

9. Naik MM, Dubey SK. Lead resistant bacteria: Lead resistance mechanisms, their applications in lead bioremediation and biomonitoring. Ecotox. Environ. Safe. 2013;98:1-7.

10. Subrahmanyam G, Shen JP, Liu YR, Archana G, Zhang LM. Effect of long-term industrial waste effluent pollution on soil enzyme activities and bacterial community composition. Environ. Monit. Assess. 2016;188:112.

11. Garcia-Gil JC, Kobza J, Soler-Rovira P, Javorekova S. Soil microbial and enzyme activities response to pollution near an aluminium smelter. Clean-Soil Air Water. 2013;41:485-492.

12. Azarbad H, Niklinska M, Laskowski R, et al. Microbial community composition and functions are resilient to metal pollution along two forest soil gradients. FEMS Microbiol. Ecol. 2015;91:1-11.

13. Niemeyer JC, Lolata GB, de Carvalho GM, Da Silva EM, Sousa JP, Nogueira MA. Microbial indicators of soil health as tools for ecological risk assessment of a metal contaminated site in Brazil. Appl. Soil Ecol. 2012;59:96-105.

14. Azarbad H, Niklinska M, van Gestel CAM, van Straalen NM,
Roling WFM, Laskowski R. Microbial community structure and functioning along metal pollution gradients. Environ. Toxicol. Chem. 2013;32:1992-2002.

15. Zhang FP, Li CF, Tong LG, et al. Response of microbial characteristics to heavy metal pollution of mining soils in central Tibet, China. Appl. Soil Ecol. 2010;45:144-151.

16. Green V, Stott D, Diack M. Assay for fluorescein diacetate hydrolytic activity: Optimization for soil samples. Soil Biol. Biochem. 2006;38:693-701.

17. Guo H, Yao J, Cai MM, et al. Effects of petroleum contamination on soil microbial numbers, metabolic activity and urease activity. Chemosphere 2012;87:1273-1280.

18. Ge TD, Nie SA, Wu JS, et al. Chemical properties, microbial biomass, and activity differ between soils of organic and conventional horticultural systems under greenhouse and open field management: A case study. J. Soil Sediment. 2010;11:25-36.

19. Chen HL, Yao J, Wang F, et al. Toxicity of three phenolic compounds and their mixtures on the gram-positive bacteria Bacillus subtilis in the aquatic environment. Sci. Total Environ. 2010;408:1043-1049.

20. Wang F, Yao J, Chen HL, Chen K, Trebse P, Zaray G. Comparative toxicity of chlorpyrifos and its oxon derivatives to soil microbial activity by combined methods. Chemosphere 2010;78:319-326.

21. Hong C, Si YX, Xing Y, Li Y. Illumina MiSeq sequencing investigation on the contrasting soil bacterial community structures in different iron mining areas. Environ. Sci. Pollut. Res. 2015;22:10788-10799.

22. Kuppusamy S, Thavamani P, Megharaj M, Venkateswarlu K, Lee YB, Naidu R. Pyrosequencing analysis of bacterial diversity in soils contaminated long-term with PAHs and heavy metals: Implications to bioremediation. J. Hazard. Mater. 2016;317: 169-179.

23. Xun WB, Huang T, Zhao J, et al. Environmental conditions rather than microbial inoculum composition determine the bacterial composition, microbial biomass and enzymatic activity of reconstructed soil microbial communities. Soil Biol. Biochem. 2015;90:10-18.

24. Bremner J, Sparks D, Page A, et al. Nitrogen-total. In: Sparks D, Page A, et al., eds. Methods of Soil Analysis Part 3 - Chemical Methods, SSSA Book Series 5.3. 1996. p. 1085-1121.

25. Wang $\mathrm{CH}$, Gu ZH, Cui H, Zhu HH, Fu SL, Yao Q. Differences in Arbuscular Mycorrhizal Fungal community composition in soils of three land use types in subtropical hilly area of Southern China. PLoS One. 2015;10:e0130983.

26. Jones DL, Simfukwe P, Hill PW, Mills RTE, Emmett BA. Evaluation of dissolved organic carbon as a soil quality indicator in national monitoring schemes. PLoS One. 2014;9:e90882.

27. Zandstra H, MacKenzie A. Potassium exchange equilibria and yield responses of oats, barley, and corn on selected Quebec soils. Soil Sci. Soc. Am. J. 1968;32:76-79.

28. Lee SS, Lim JE, El-Azeem SAA, et al. Heavy metal immobilization in soil near abandoned mines using eggshell waste and rapeseed residue. Environ. Sci. Pollut. Res. 2013;20:1719-1726.

29. Yuan ZM, Zhao Y, Guo ZW, Yao J. Chemical and ecotoxicological assessment of multiple heavy metal-contaminated soil treated by phosphate addition. Water Air Soil Pollut. 2016;227:403 
30. Chen HL, Yao J, Wang F, et al. Investigation of the acute toxic effect of chlorpyrifos on Pseudomonas putida in a sterilized soil environment monitored by microcalorimetry. Arch. Environ. Con. Tox. 2010;58:587-593.

31. Zhang W, Chen L, Zhang R, Lin KF. High throughput sequencing analysis of the joint effects of BDE209-Pb on soil bacterial community structure. J. Hazard. Mater. 2016;301:1-7.

32. Mondal NK, Dey U, Ghosh S, Datta JK. Soil enzyme activity under arsenic-stressed area of Purbasthali, West Bengal, India. Arch. Agron. Soil Sci. 2015;61:73-87.

33. Niu FJ, He JX, Zhang GS, et al. Effects of enhanced UV-B radiation on the diversity and activity of soil microorganism of alpine meadow ecosystem in Qinghai-Tibet Plateau. Ecotoxicology 2014;23:1833-1841.

34. Mignardi S, Corami A, Ferrini V. Evaluation of the effectiveness of phosphate treatment for the remediation of mine waste soils contaminated with $\mathrm{Cd}, \mathrm{Cu}, \mathrm{Pb}$, and $\mathrm{Zn}$. Chemosphere 2012;86:354-360.

35. Osborne LR, Baker LL, Strawn DG. Lead immobilization and phosphorus availability in phosphate-amended, mine-contaminated soils. J. Environ. Qual. 2015;44:183-190.

36. Cao XD, Wahbi A, Ma LN, Li B, Yang YL. Immobilization of $\mathrm{Zn}, \mathrm{Cu}$, and $\mathrm{Pb}$ in contaminated soils using phosphate rock and phosphoric acid. J. Hazard. Mater. 2009;164:555-564.

37. Masakorala K, Yao J, Chandankere R, et al. A combined ap- proach of physicochemical and biological methods for the characterization of petroleum hydrocarbon-contaminated soil. Environ. Sci. Pollut. Res. 2014;21:454-463.

38. Mejias Carpio IE, Franco DC, Zanoli Sato MI, et al. Biostimulation of metal-resistant microbial consortium to remove zinc from contaminated environments. Sci. Total Environ. 2016;550:670-675.

39. Ho L, Hoefel D, Saint CP, Newcombe G. Isolation and identification of a novel microcystin-degrading bacterium from a biological sand filter. Water Res. 2007;41:4685-4695.

40. Tangaromsuk J, Pokethitiyook P, Kruatrachue M, Upatham ES. Cadmium biosorption by Sphingomonas paucimobilis biomass. Bioresour. Technol. 2002;85:103-105.

41. Quadros PDd, Zhalnina K, Davis-Richardson AG, et al. Coal mining practices reduce the microbial biomass, richness and diversity of soil. Appl. Soil Ecol. 2016;98:195-203.

42. Lombardi AT, Garcia Jr O. Biological leaching of Mn, Al, Zn, $\mathrm{Cu}$ and $\mathrm{Ti}$ in an anaerobic sewage sludge effectuated by Thiobacillus ferrooxidans and its effect on metal partitioning. Water Res. 2002;36:3193-3202.

43. Kai T, Suenaga Y-i, Migita A, Takahashi T. Kinetic model for simultaneous leaching of zinc sulfide and manganese dioxide in the presence of iron-oxidizing bacteria. Chem. Eng. Sci. 2000;55:3429-3436. 